\title{
Thermoneutral Operation of Solid Oxide Electrolysis Cells in Potentiostatic Mode
}

Chen, Ming; Sun, Xiufu; Chatzichristodoulou, Christodoulos; Koch, Søren; Hendriksen, Peter Vang; Mogensen, Mogens Bjerg

\author{
Published in: \\ E C S Transactions \\ Link to article, DOI: \\ 10.1149/07801.3077ecst \\ Publication date: \\ 2017 \\ Document Version \\ Peer reviewed version \\ Link back to DTU Orbit
}

Citation (APA):

Chen, M., Sun, X., Chatzichristodoulou, C., Koch, S., Hendriksen, P. V., \& Mogensen, M. B. (2017).

Thermoneutral Operation of Solid Oxide Electrolysis Cells in Potentiostatic Mode. E C S Transactions, 78(1), 3077-3088. https://doi.org/10.1149/07801.3077ecst

\section{General rights}

Copyright and moral rights for the publications made accessible in the public portal are retained by the authors and/or other copyright owners and it is a condition of accessing publications that users recognise and abide by the legal requirements associated with these rights.

- Users may download and print one copy of any publication from the public portal for the purpose of private study or research.

- You may not further distribute the material or use it for any profit-making activity or commercial gain

- You may freely distribute the URL identifying the publication in the public portal 


\title{
Thermoneutral Operation of Solid Oxide Electrolysis Cells in Potentiostatic Mode
}

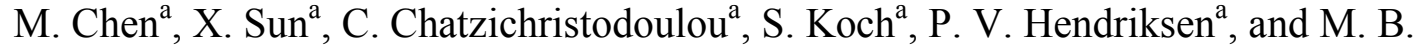 \\ Mogensen $^{\mathrm{a}}$ \\ ${ }^{a}$ Department of Energy Conversion and Storage, Technical University of Denmark, \\ Roskilde 4000, Denmark
}

\begin{abstract}
High temperature electrolysis based on solid oxide electrolysis cells (SOECs) is a promising technology for energy storage and synthetic fuel production. In recent years extensive efforts have been devoted to improving performance and durability of SOEC cells and stacks. Due to historical reasons and the convenience of doing constant current tests, (almost) all the reported SOEC tests have been galvanostatic. In this work, we report test results on two types of SOEC cells operated for electrolysis of steam in potentiostatic mode at $1.29 \mathrm{~V}$. Both cells are Ni/YSZ fuel electrode supported type with different oxygen electrodes. The two cells exhibited different initial performance and different long-term degradation behavior. Detailed impedance analysis indicates that degradation happened mainly at the Ni/YSZ electrode for both cells. Large overpotential on the Ni/YSZ electrode was identified as the main cause of the degradation. Operation strategies were further proposed for electrolysis operation in potentiostatic mode.
\end{abstract}

\section{Introduction}

High temperature electrolysis based on solid oxide electrolysis cells (SOECs) is a very promising technology for energy storage and production of synthetic fuels. Compared with conventional low temperature electrolysis cells, SOEC has several advantages. The high operating temperature results in faster reaction kinetics and lower internal resistance. Besides, the heat demand required for electrolysis can be obtained from the Joule heat originating from the cell internal resistance or from renewable or waste heat sources, thus reducing the total electrical energy demand. A close to $100 \%$ electricity-to-fuel efficiency can be reached if the SOEC is operated at the thermoneutral voltage (defined as the minimum thermodynamic voltage at which a perfectly insulated electrolysis unit would operate isothermally, if there is no net inflow or outflow of heat) (1).

In recent years extensive efforts have been devoted to improving performance and durability of SOEC cells and stacks. A number of long-term single cell or stack tests have been reported by various groups, with the longest testing period reaching 23,000 hours (2-4). Due to historical reasons and the convenience of doing constant current tests, (almost) all the reported SOEC tests have been galvanostatic. The cell voltages were either below or above the thermoneutral voltage $(\sim 1.29 \mathrm{~V}$ for electrolysis of steam), resulting in an exothermic or endothermic electrolysis process, respectively. From a SOEC system point of view, it is highly desirable to operate the SOEC at constant 
thermoneutral voltage (or slightly above in order to account for potential heat losses), to ensure high efficiency and to ease the heat management of SOEC stacks and systems. Besides, from a testing point of view, the natural test method should be potentiostatic (constant voltage), because the electrochemical driving force of an electrode process is the overpotential, which is directly related to the cell voltage, and most probably some future applications will ask for constant voltage output.

The aim of this work is to investigate long-term degradation behavior of SOEC cells when operated for electrolysis of steam in potentiostatic mode at thermoneutral voltage. We report test results on two types of SOEC cells, both Ni/YSZ fuel electrode supported type but with different oxygen electrodes. The different degradation behavior of the two cells is explained by detailed impedance analysis and 2-D electrochemical modeling.

\section{Experimental}

\section{$\underline{\text { Cell specification and test set-up }}$}

Two Ni/YSZ fuel electrode supported SOECs (hereafter referred to as Cell A and B) were manufactured using nominally identical half cells consisting of a Ni/YSZ support ( $\sim 300 \mu \mathrm{m}$ in thickness), a Ni/YSZ fuel electrode ( $10 \mu \mathrm{m}$ in thickness), and an YSZ electrolyte $\left(\sim 8 \mu \mathrm{m}\right.$ in thickness). Cell $\mathrm{A}$ further has a $\mathrm{CGO} 10\left(\mathrm{Ce}_{0.9} \mathrm{Gd}_{0.1} \mathrm{O}_{1.95}\right)$ interdiffusion barrier layer $(\sim 8 \mu \mathrm{m}$ in thickness) and a LSCF/CGO (LSCF: $\left.\mathrm{La}_{0.6} \mathrm{Sr}_{0.4} \mathrm{Co}_{0.2} \mathrm{Fe}_{0.8} \mathrm{O}_{3-\delta}\right)$ oxygen electrode sequentially screen printed onto the cell. For Cell B, a thin CGO layer ( $\sim 2 \mu \mathrm{m}$ in thickness) was applied using physical vapor deposition (PVD) before an LSC/CGO (LSC: $\left.\left(\mathrm{La}_{0.6} \mathrm{Sr}_{0.4}\right)_{0.99} \mathrm{CoO}_{3-\delta}\right)$ oxygen electrode was screen printed and sintered. Both cells have a foot print of $5.3 \times 5.3 \mathrm{~cm}^{2}$ and an active electrode area of $4 \times 4 \mathrm{~cm}^{2}$. The setup for single cell testing was illustrated and described in detail previously (5-6). In this work, steel spacers and glass felt with glass softening and glass transition temperatures of approximately $670{ }^{\circ} \mathrm{C}$ and $790{ }^{\circ} \mathrm{C}$ respectively were used to seal the fuel and oxygen electrode gas flow compartments. Corrugated gold and nickel meshes as gas distribution layers and gold and nickel plates as current collector components were used on the oxygen and fuel electrode side, respectively. To ensure gas tight sealants and electrical contact between the cell and the contact components, eight kilograms of weight was applied on top of the cell house during start up.

The cells were heated $\left(1{ }^{\circ} \mathrm{C} / \mathrm{min}\right)$ to $850{ }^{\circ} \mathrm{C}$ for sealing and the fuel electrode was reduced first in $9 \% \mathrm{H}_{2}$ in Ar for $2 \mathrm{~h}$, followed by another $2 \mathrm{~h}$ in humidified $\mathrm{H}_{2}\left(4 \% \mathrm{H}_{2} \mathrm{O}\right)$. The electrochemical performance of the cells was characterized at 850,800 , and $750{ }^{\circ} \mathrm{C}$, both before and after the long-term durability test. At each temperature, DC polarization $(i V)$ curves and AC electrochemical impedance (EIS) measurements were carried out, with $50 \mathrm{l} / \mathrm{h}$ air or pure oxygen supplied to the oxygen electrode and $24 \mathrm{l} / \mathrm{h} \mathrm{H}_{2} \mathrm{O} / \mathrm{H}_{2}(4,20$, and $50 \% \mathrm{H}_{2} \mathrm{O}$ ) to the fuel electrode. The potentiostatic durability test was conducted at $750{ }^{\circ} \mathrm{C}$, with $30 \mathrm{l} / \mathrm{h}$ pure oxygen supplied to the oxygen electrode and $24 \mathrm{l} / \mathrm{h} \mathrm{H}_{2} \mathrm{O} / \mathrm{H}_{2}$ $(50 / 50)$ to the fuel electrode. The cells were operated at $1290 \mathrm{mV}$, i.e. thermoneutral voltage for electrolysis of steam. During the durability test period, the cells were brought to open circuit voltage (OCV) regularly to measure cell voltage and EIS. 


\section{$\underline{\text { Potentiostatic control }}$}

Usually when testing SOEC cells, the DC current through the cell is controlled galvanostatically (that is a fixed current is specified) as this makes it easier to avoid too high current which could result in damage to the cell (for instance by trying to convert more gas than is being supplied). To operate the cell potentiostatically, a software proportional integral derivative (PID) device was developed in this work in order to adjust the DC current so that the resulting cell voltage matches the desired target value (1290 $\mathrm{mV}$ in this work). A schematic illustration of the PID device is presented in Figure 1. The control loop consists of an input device (the cell voltage), a PID device and an output device (the DC power supply unit (PSU) in galvanostatic mode). The PID device compares the actual cell voltage with the user specified set point and adjusts the DC current accordingly. To be able to switch to and from potentiostatic control, an output enabled input (user controllable manual relay in Figure 1) is used. This "virtual" relay can be set to ON or OFF when the SOEC cell is in potentiostatic or galvanostatic mode, respectively. This enables us to acquire EIS (under current or at OCV) during the potentiostatic durability test period by just switching off the PID loop during the impedance acquisition. In order to make the switch from galvanostatic to potentiostatic control as smooth as possible, first the DC current is set manually so that the cell voltage is close to the desired target. Before enabling potentiostatic control, an integrated error is set to an appropriate value. Otherwise a large accumulated error could result in large deviations before the PID loop stabilizes. Switching from potentiostatic to galvanostatic control is straight forward, just by setting the "virtual" relay to OFF.

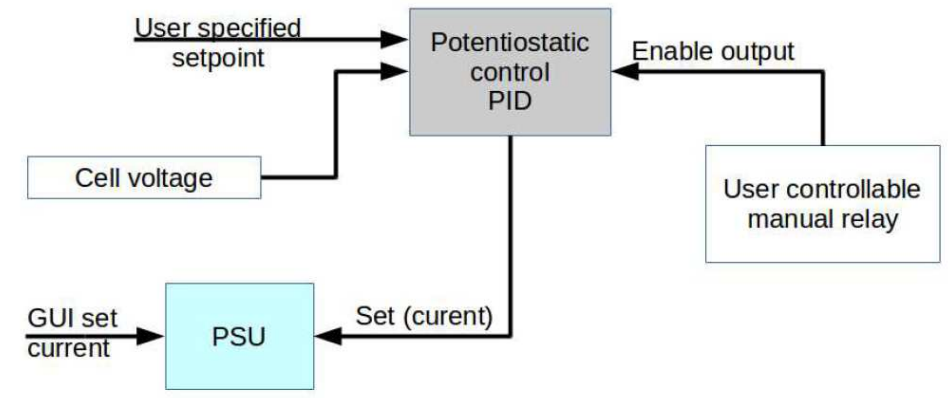

Figure 1. Schematic illustration of a PID device used to control a galvanostatic DC power supply to emulate potentiostatic control. The user controllable manual (virtual) relay is used to switch to and from potentiostatic control.

\section{Electrochemical impedance spectroscopy (EIS) and electrochemical potential profile}

A Solartron 1255 frequency analyzer was used for recording EIS both at OCV and under current. Impedance spectra (IS) were recorded with 12 points/decade in a frequency range from 82451 to $0.08 \mathrm{~Hz}$ and were corrected using the short circuit impedance response of the test setup. In this work, impedance spectra are presented in Nyquist plots. Furthermore, plots of distribution of relaxation times (DRT) are provided. The DRT plots are used to illustrate development of impedance over time and to highlight frequency ranges for different processes contributing to the total impedance response from the cells (7-8). To quantitatively break down losses, complex-non-linearleast-squares (CNLS) method was used to fit an equivalent circuit model to the IS data measured at OCV. The model used previously by Hjalmarsson et al. and Sun et al. for the 
same types of Ni/YSZ electrode supported SOEC cells was adopted in this work $(3,6,9)$ : $L-R_{\mathrm{S}}-(R Q)_{\text {ion }}-(R Q)_{\mathrm{Ni} / Y \mathrm{SZ} \mathrm{TPB}}-G_{\mathrm{LSC}(\mathrm{F}) / \mathrm{CGO}}-(R Q)_{\mathrm{DIFF}}-(R Q)_{\mathrm{CONV}} .(R Q)_{\text {ion }}$ corresponds to the high frequency arc at $\sim 10-40 \mathrm{kHz}$ and accounts for the ionic transport process through the ionic conducting matrix in the electrodes. For the types of SOEC cells investigated in this work, with the mixed ionic electronic and highly ionic conducting LSCF/CGO or LSC/CGO oxygen electrode, $(R Q)_{\text {ion }}$ can be expected to originate mainly from the $\mathrm{Ni} / \mathrm{YSZ}$ electrode $(10)$. The $(R Q)_{\mathrm{Ni} / \mathrm{YSZ}}$ TPB at $\sim 1-4 \mathrm{kHz}$ is ascribed to the electrochemical process at the triple phase boundaries (TPBs) of the Ni/YSZ electrode. The impedance response from the LSCF/CGO or LSC/CGO oxygen electrode is approximated by a Gerisher element, having a characteristic frequency of $\sim 100 \mathrm{~Hz}$. Finally, gas diffusion and gas conversion resistance contributions as described by Primdahl and Mogensen are approximated by two RQ-circuits having characteristic frequencies around $\sim 40 \mathrm{~Hz}$ and $\sim 2 \mathrm{~Hz}$, respectively (11-12).

The results from the CNLS fitting, i.e. the resistances of the different electrochemical processes, were provided as inputs to a two dimensional bi-layer electrolyte solid oxide cell (SOC) model developed by Chatzichristodoulou and co-workers (13). The model includes activation, concentration, and conversion losses for both fuel and oxygen electrodes and is capable of simulating chemical and electrochemical potential distribution across the electrolyte and along the gas flow under varying operating conditions for a large set of electrode, electrolyte, and cell characteristics. With the model and the cell characteristics from this work, the overpotential distribution along the steam/hydrogen flow direction was simulated. The results were further correlated with the degradation behavior of the two cells tested in this work.

\section{Results and discussion}

Figure 2 plots the results from $i V$ polarization measurements of Cell A and Cell B recorded at $750{ }^{\circ} \mathrm{C}$ before and after the durability tests. The results clearly show that initially Cell B has a lower resistance than Cell A in both SOEC and SOFC modes. At $1250 \mathrm{mV}$, Cell A has reached a current density of $-0.76 \mathrm{~A} / \mathrm{cm}^{2}$ while Cell B has reached $0.99 \mathrm{~A} / \mathrm{cm}^{2}$. The secant resistance at $1250 \mathrm{mV}$ is calculated to be $0.35 \Omega \mathrm{cm}^{2}$ and $0.27 \Omega$ $\mathrm{cm}^{2}$ for Cell A and B, respectively. Both types of cells have been tested previously in coelectrolysis mode, where Cell B also showed better initial performance than Cell A $(6,9)$. The difference in the cell initial performance should be ascribed to the different barrier layers and the different oxygen electrodes. Cell B has a LSC/CGO oxygen electrode. LSC is well known for its good mixed ionic and electronic conducting (MIEC) properties and its high catalytic activity toward oxygen reduction, being superior to LSCF. Cell B has in addition a thin $(\sim 2 \mu \mathrm{m})$ and dense CGO inter-diffusion barrier layer applied by PVD. This reduces the cell resistance not only due to the lower ohmic resistance of the PVD barrier layer but also by efficiently preventing Sr diffusion toward the electrolyte and formation of insulating $\mathrm{SrZrO}_{3}$ (14). In addition, the thin CGO barrier layer applied by the low-temperature PVD technique avoids high sintering temperature, which is often required for the CGO barrier layer applied by e.g. screen printing (Cell A). The high temperature sintering process for the CGO barrier layer promotes inter-diffusion between CGO and YSZ, resulting in formation of a solid solution with an ionic conductivity lower than that of CGO and YSZ (15-16). After the long-term potentiostatic tests, both cells have reached similar performance in SOEC mode while in SOFC mode Cell B has 
slightly better performance than Cell A. At $1250 \mathrm{mV}$, Cell A and B have reached a current density of -0.52 and $-0.53 \mathrm{~A} / \mathrm{cm}^{2}$, respectively. The secant resistance is calculated to be $0.51 \Omega \mathrm{cm}^{2}$ for both cells.

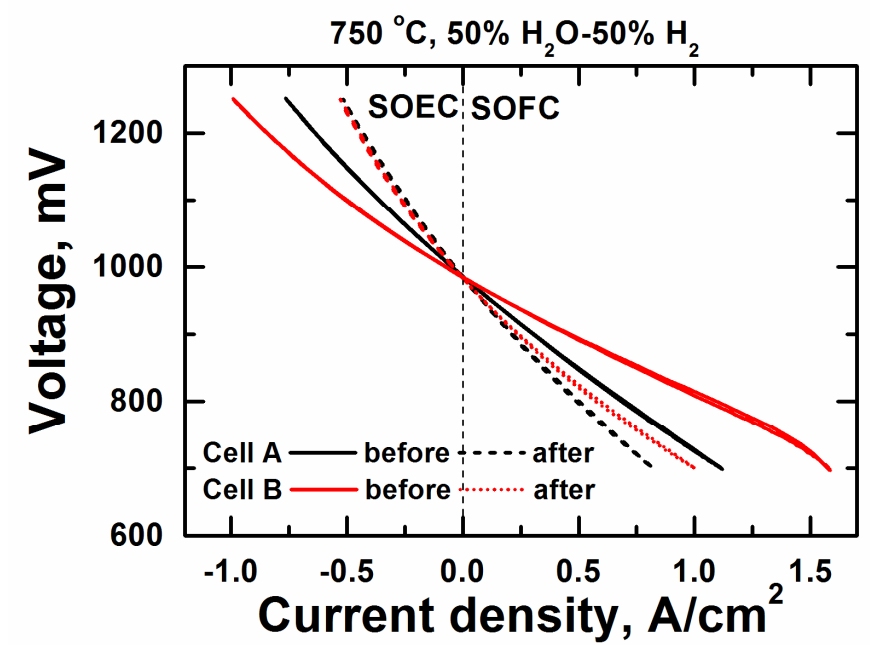

Figure 2. Representative cell performance of the two SOEC cells tested in this work. The $i V$ characterization was carried out at $750{ }^{\circ} \mathrm{C}$, with $24 \mathrm{1} / \mathrm{h} \mathrm{H}_{2} \mathrm{O}+\mathrm{H}_{2}$ mixture $\left(\mathrm{H}_{2} \mathrm{O} / \mathrm{H}_{2}=\right.$ 50/50) supplied to the $\mathrm{Ni} / \mathrm{YSZ}$ electrode and $50 \mathrm{1} / \mathrm{h} \mathrm{O}_{2}$ to the LSCF/CGO (Cell A) or LSC/CGO (Cell B) oxygen electrode.

The durability tests were conducted at $750{ }^{\circ} \mathrm{C}$ and $1290 \mathrm{mV}$. Figure 3 provides an overview of cell voltage and current density for Cell A and Cell B during the potentiostatic durability test period. The conversion of steam into hydrogen is calculated to be $56 \%$ (theoretically) at $-1 \mathrm{~A} / \mathrm{cm}^{2}$ with $24 \mathrm{l} / \mathrm{h} \mathrm{H}_{2} \mathrm{O}+\mathrm{H}_{2}$ mixture $\left(\mathrm{H}_{2} \mathrm{O} / \mathrm{H}_{2}=50 / 50\right)$ to the Ni/YSZ electrode. The durability test for Cell A lasted for approximately $1550 \mathrm{~h}$. At $1290 \mathrm{mV}$, it started at a current density of $-0.81 \mathrm{~A} / \mathrm{cm}^{2}$, decreased to $-0.41 \mathrm{~A} / \mathrm{cm}^{2}$ after the first $450 \mathrm{~h}$ fast degradation, and afterwards slowly reactivated and reached $-0.55 \mathrm{~A} / \mathrm{cm}^{2}$ at $1550 \mathrm{~h}$. Cell A was brought to OCV 18 times within the entire $1550 \mathrm{~h}$. The cell voltages measured at OCV are between 982 and $986 \mathrm{mV}$, very close to the theoretical EMF of $50 \% \mathrm{H}_{2} \mathrm{O}+50 \% \mathrm{H}_{2}$ versus oxygen $(991 \mathrm{mV})$. This indicates that good sealing of the cell was maintained during the test and that the SOEC-OCV-SOEC load cycles have no detrimental effect to it. Also the load cycles have caused no damage to the cell performance as the cell has reached the same or even slightly higher current density as before. Due to the better initial performance, Cell B started at a current density of -1.09 $\mathrm{A} / \mathrm{cm}^{2}$ at $1290 \mathrm{mV}$. It degraded all the time during the entire testing period and eventually reached $-0.54 \mathrm{~A} / \mathrm{cm}^{2}$ after $2230 \mathrm{~h}$. The cell was brought to OCV 19 times and the cell voltage was measured to be $980-985 \mathrm{mV}$. The different degradation behavior of Cell A and $\mathrm{B}$ is further elaborated in Figure 4, where the current density at $1290 \mathrm{mV}$ and its time derivative $(\delta(i) / \delta(t))$ are plotted. Different from most of the previously reported tests in galvanostatic mode where the degradation rate is calculated in term of voltage change per unit time, here the degradation rate is plotted in term of current density change per unit time as the tests were run in potentiostatic mode. As shown by the $\delta(i) / \delta(t)$ curves, Cell A has experienced three stages: accelerated degradation $(0-450 \mathrm{~h})$, activation $(450-900 \mathrm{~h})$, and stabilization/steady state degradation (900-1550 h). Cell B seems to have gone through only two stages: accelerated degradation $(0-1000 \mathrm{~h})$ and stabilization/steady state degradation (1000-2230 h). Though started with different initial performance, Cell A and 
B have reached similar steady state performance (about $-0.55 \mathrm{~A} / \mathrm{cm}^{2}$ at $1290 \mathrm{mV}$ ) after $1500-2200 \mathrm{~h}$ testing.
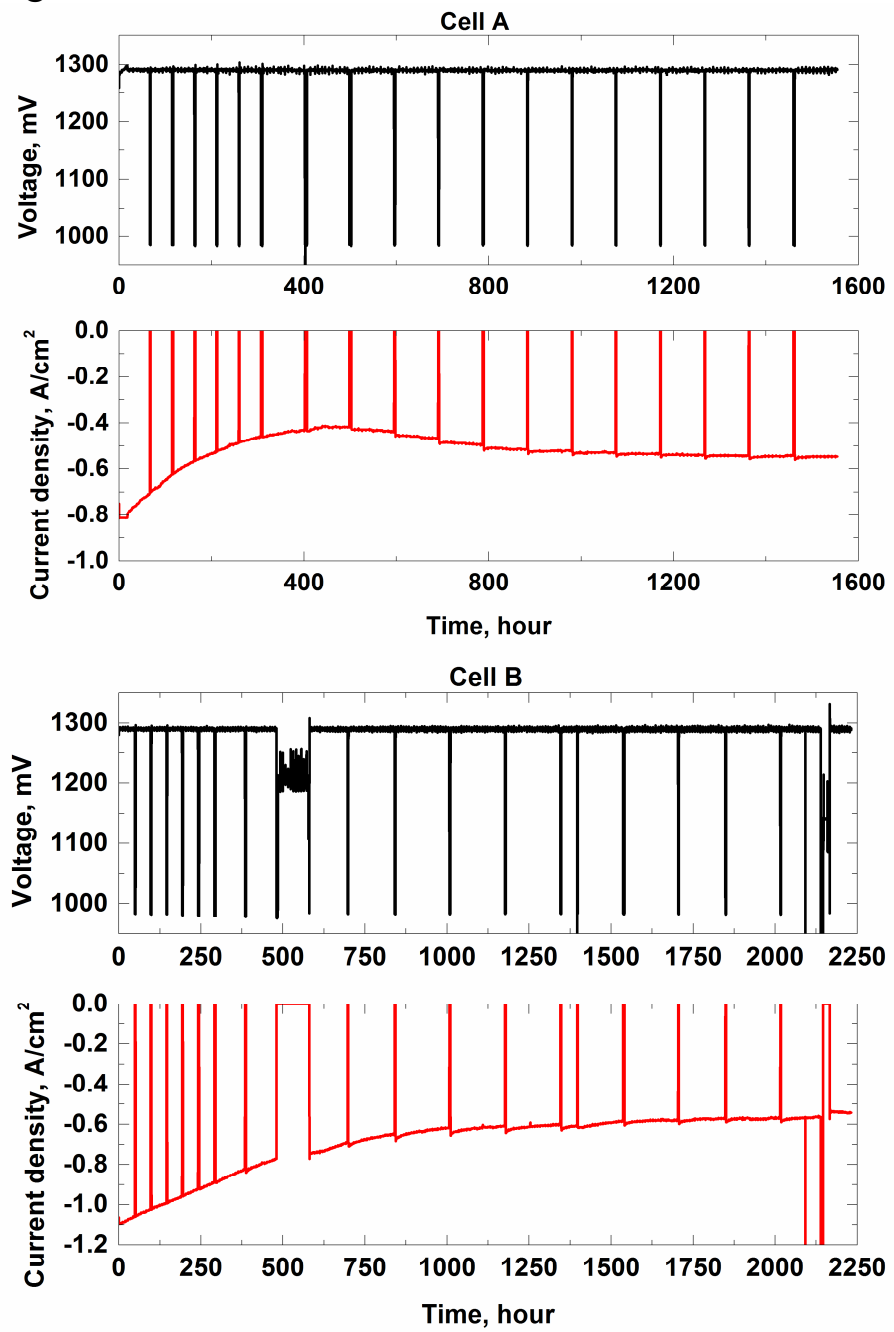

Figure 3. Overview of cell voltage and current density for Cell A and Cell $\mathrm{B}$ during the potentiostatic durability test period. The cells were supplied with $24 \mathrm{l} / \mathrm{h} \mathrm{H}_{2} \mathrm{O}+\mathrm{H}_{2}$ mixture $\left(\mathrm{H}_{2} \mathrm{O} / \mathrm{H}_{2}=50 / 50\right)$ to the $\mathrm{Ni} / \mathrm{YSZ}$ electrode and $30 \mathrm{l} / \mathrm{h} \mathrm{O}_{2}$ to the $\mathrm{LSCF} / \mathrm{CGO}$ or $\mathrm{LSC} / \mathrm{CGO}$ oxygen electrode.
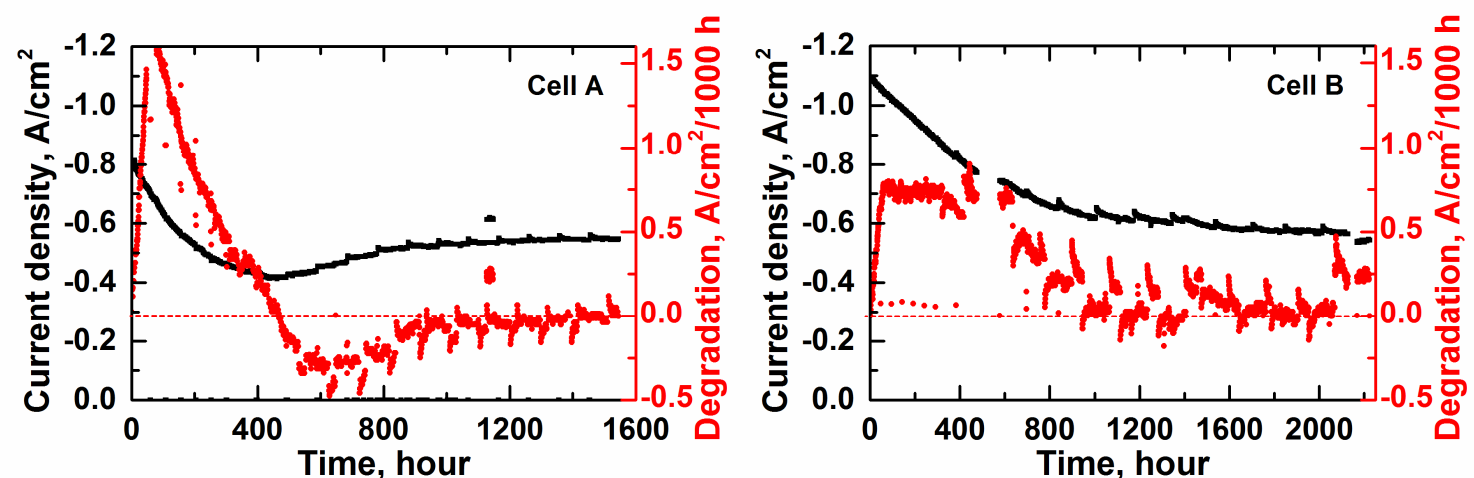

Figure 4. Evolution of the current density and its time derivative for Cell A (top) and Cell $\mathrm{B}$ operated in potentiostatic mode at $750{ }^{\circ} \mathrm{C}$ and $1290 \mathrm{mV}$. 
To provide a more detailed view on the increase of the resistances, IS recorded during the potentiostatic durability test period is presented in Figure 5 including the corresponding DRT. Figure 6 plots values for ohmic resistance, electrode polarization resistance, and gas diffusion and conversion resistance deduced from the IS. In this study, the gas flow was kept constant during the entire durability test period. When the cell is operated at $1290 \mathrm{mV}$ in potentiostatic mode, the current density and the corresponding gas conversion vary with time due to cell degradation. This introduces extra complexity to the quantitative analysis of IS measured under current, as the gas diffusion and gas conversion resistance contributions vary with time as well. Therefore, in this work only the IS recorded at OCV was analyzed in detail. From Figures 5 and 6 it is evident that the degradation was caused mainly by the increase in the electrode polarization resistance and to a smaller degree by the increase in the ohmic resistance. The changes in the DRT plots happen in a frequency range of $1-10 \mathrm{kHz}$ for Cell A and also down to $100 \mathrm{~Hz}$ for Cell B. It can be concluded that the two high frequency electrochemical processes $\left(R_{\text {ion }}\right.$ and $\left.R_{\mathrm{Ni} / \mathrm{TSZ}} \mathrm{TPB}\right)$ contributes significantly to the electrode polarization resistance increase for both Cell A and B. This degradation happened throughout the entire test period for Cell B, whereas for Cell A it happened only in the first $450 \mathrm{~h}$ and afterwards it actually activated.

Figure 7 plots four impedance spectra at OCV of the two cells recorded before and after the durability test. The key results for resistance contributions and characteristic frequencies obtained from CNLS fitting of these IS are summarized in Table I. Within the uncertainties in CNLS fitting, initially Cell A and B have the same resistance

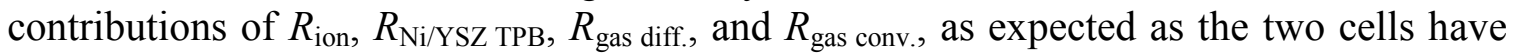
nominally identical half cells. The superior LSC/CGO oxygen electrode and thin and dense PVD CGO barrier layer results in a much smaller $R_{\mathrm{s}}$ and $R_{\mathrm{LSC}(\mathrm{F}) / \mathrm{CGO}}$ for Cell B as compared to those for Cell A. Overall Cell B has an ASR accounting to only $69 \%$ of that of Cell A initially. This advantage however does not lead to lower degradation rate when the two cells were tested at $1290 \mathrm{mV}$ in potentiostatic mode. The difference in testing period (1550 h for Cell A and $2230 \mathrm{~h}$ for Cell B) should not matter in this case, as for both cells degradation happened mainly in the first $500 \mathrm{~h}$. For both cells, the degradation originates mainly from an increase in $R_{\mathrm{Ni} / \mathrm{YSZ} \text { TPB }}$ and to a smaller degree in $R_{\mathrm{s}}$. For Cell $\mathrm{B}$, $R_{\mathrm{Ni} / \mathrm{YSZ} \text { TPB }}$ has increased by a factor of three after the durability test and is higher than that of Cell $\mathrm{A}$ after the test. This means that an improvement on the oxygen electrode side (including the barrier layer) has actually resulted in large degradation in the Ni/YSZ electrode when the cells were tested in potentiostatic mode at $1290 \mathrm{mV}$. Due to overlap in the frequency range of $\mathrm{LSCF} / \mathrm{CGO}$ or $\mathrm{LSC} / \mathrm{CGO}$ with that of $\mathrm{Ni} / \mathrm{YSZ}$, the interpretation of $R_{\mathrm{LSC}(\mathrm{F}) / \mathrm{CGO}}$ and its degradation should be treated with caution. This however will not change the overall degradation picture, as the oxygen electrode resistance accounts only $5-10 \%$ of the overall cell resistance for both cells. 

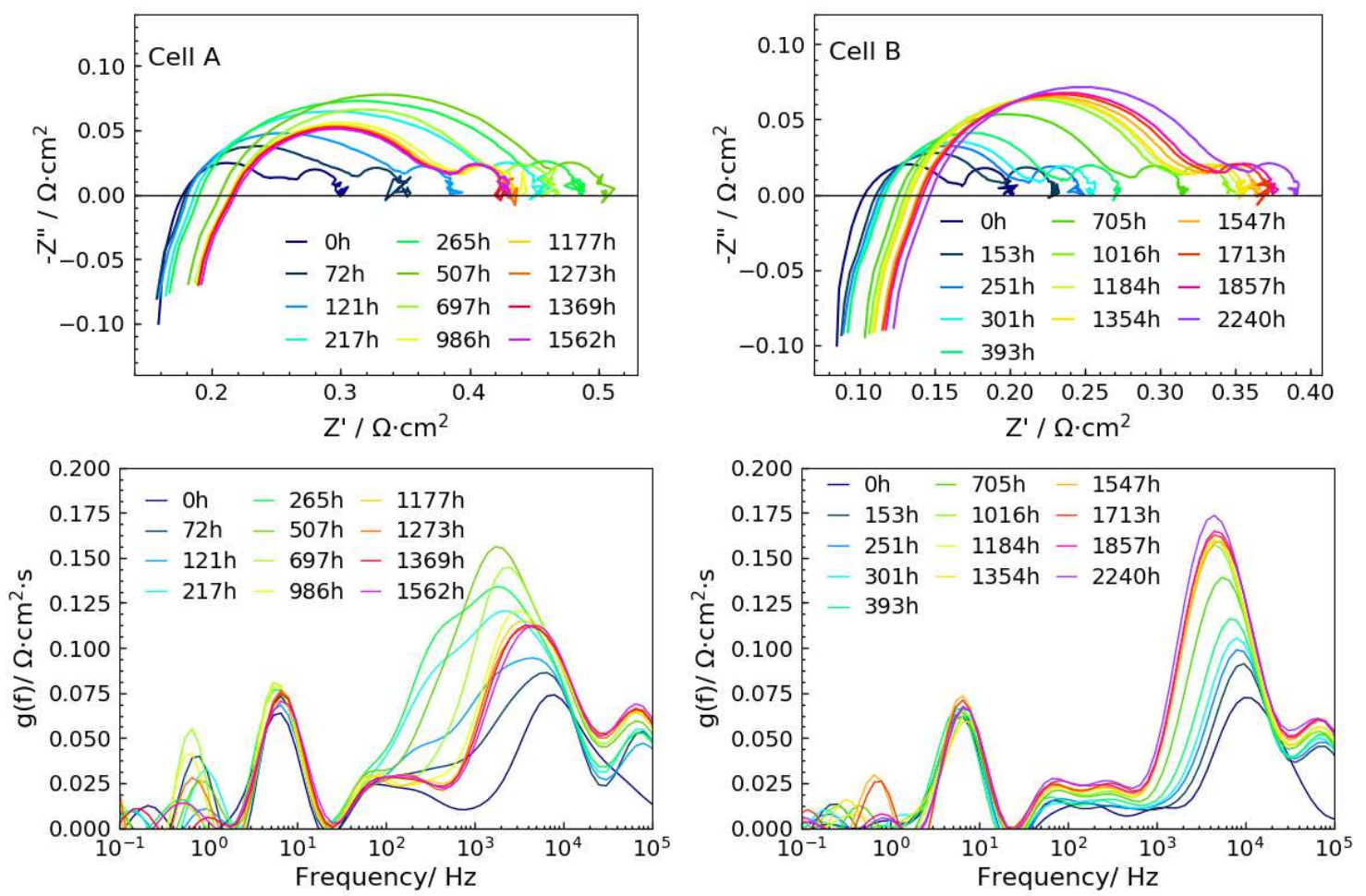

Figure 5. Nyquist (top) and DRT (bottom) plots of IS for Cell A and Cell B recorded at OCV during the potentiostatic durability test period.
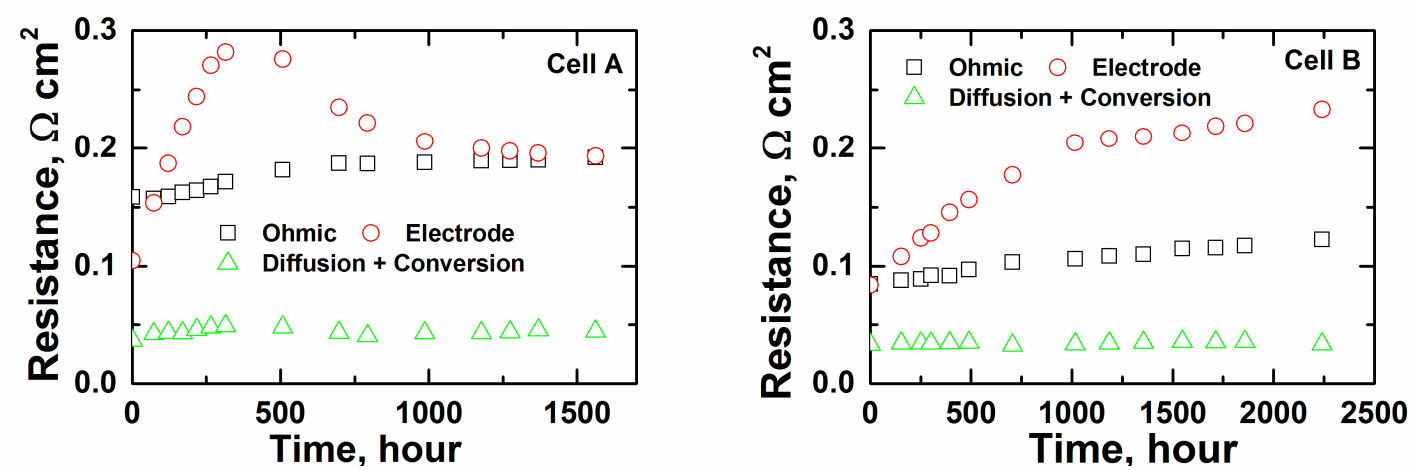

Figure 6. Ohmic resistances, electrode polarization resistances, and gas diffusion and conversion polarization resistances for Cell A and Cell B deduced from IS recorded at OCV during the potentiostatic durability test period. 

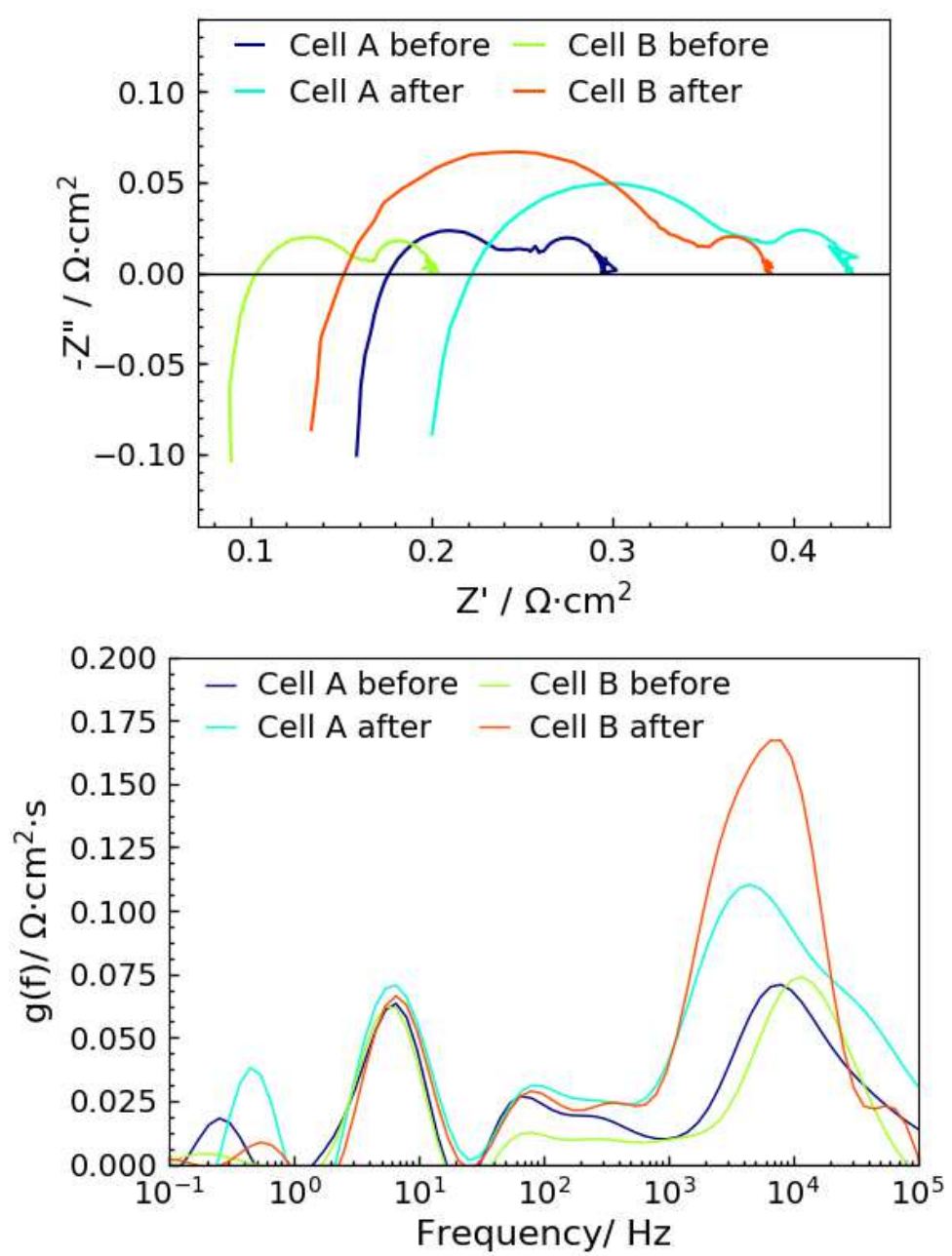

Figure 7. Nyquist and DRT plots of IS recorded before and after the potentiostatic durability test period. The IS was recorded at $750{ }^{\circ} \mathrm{C}$, OCV, with $24 \mathrm{l} / \mathrm{h} \mathrm{H}_{2} \mathrm{O}+\mathrm{H}_{2}$ mixture $\left(\mathrm{H}_{2} \mathrm{O} / \mathrm{H}_{2}=50 / 50\right)$ to the $\mathrm{Ni} / \mathrm{YSZ}$ electrode and $30 \mathrm{l} / \mathrm{h} \mathrm{O}_{2}$ to the LSCF/CGO or LSC/CGO oxygen electrode.

Table I. Results from equivalent circuit modeling of IS presented in Figure 7.

\begin{tabular}{lllll}
\hline & Cell A, before & Cell A, after & Cell B, before & Cell B, after \\
\hline$R_{\mathrm{s}}, \Omega \mathrm{cm}^{2}$ & 0.154 & 0.189 & 0.075 & 0.116 \\
\hline$R_{\text {ion }}, \Omega \mathrm{cm}^{2}$ & 0.018 & 0.030 & 0.016 & 0.025 \\
\hline$f_{\text {ion }}, \mathrm{kHz}$ & 34.1 & 42.0 & 76.3 & 51.7 \\
\hline$R_{\mathrm{N} / \mathrm{YSZ} \mathrm{TPB}}, \Omega \mathrm{cm}^{2}$ & 0.058 & 0.141 & 0.062 & 0.186 \\
\hline$f_{\mathrm{Ni} / \mathrm{YSZ} \mathrm{TPB}}, \mathrm{kHz}$ & 7.2 & 4.9 & 10.6 & 5.6 \\
\hline$R_{\mathrm{LS}(\mathrm{C}) \mathrm{F} / \mathrm{CGO}}, \Omega \mathrm{cm}^{2}$ & 0.026 & 0.018 & 0.012 & 0.019 \\
\hline$f_{\mathrm{LS}(\mathrm{C}) \mathrm{F} / \mathrm{CGO}}, \mathrm{Hz}$ & 152 & 183 & 262 & 158 \\
\hline$R_{\text {gas diff., }}, \Omega \mathrm{cm}^{2}$ & 0.004 & 0.006 & 0.003 & 0.005 \\
\hline$f_{\text {gas diff., }}, \mathrm{Hz}$ & 69 & 80 & 66 & 80 \\
\hline$R_{\text {gas conv. }}, \Omega \mathrm{cm}^{2}$ & 0.034 & 0.045 & 0.032 & 0.035 \\
\hline$f_{\text {gas conv. }}, \mathrm{Hz}$ & 5 & 7 & 5 & 7 \\
\hline$A S R, \Omega \mathrm{cm}^{2}$ & 0.294 & 0.429 & 0.200 & 0.386 \\
\hline
\end{tabular}

Previously we reported that the SOEC cell with better oxygen electrode (i.e. LSCF/CGO versus LSM/YSZ, or LSC/CGO versus LSCF/CGO) showed lower degradation rate when tested in galvanostatic mode $(6,9)$. In this work we obtained different findings when we tested the same type of cells in potentiostatic mode. The 
degradation of the SOEC cell or its electrode is essentially driven by the electrode overpotentials. The polarization values can be roughly estimated by multiplying resistance with current density. When the SOEC cells are tested in galvanostatic mode, improving the oxygen electrode will result in a decrease in both the overall cell overpotential and the oxygen electrode part and hence eventually a decrease in cell degradation. In potentiostatic mode, the overall cell overpotential is fixed as the difference between the target cell voltage (constant) and the EMF. Improving any part of the cell will in most cases lead to higher initial current density and will influence how the electrode overpotential is distributed. To further clarify this, the CNLS fitting results shown in Table I (only those before the durability test) were provided as inputs to the SOC model developed by Chatzichristodoulou and co-workers (13). Figure 8 plots simulated current distribution along the hydrogen/steam flow direction at the beginning of the potentiostatic durability test period (i.e. $0 \mathrm{~h}$ ), when the cells are operated at $750{ }^{\circ} \mathrm{C}$ and $1290 \mathrm{mV}$. It is no surprise that due to superior initial performance Cell B reached higher current density than Cell A. Both cells have higher local current density at the inlet than at the outlet. Cell B has a steeper slope in the current distribution than Cell A.

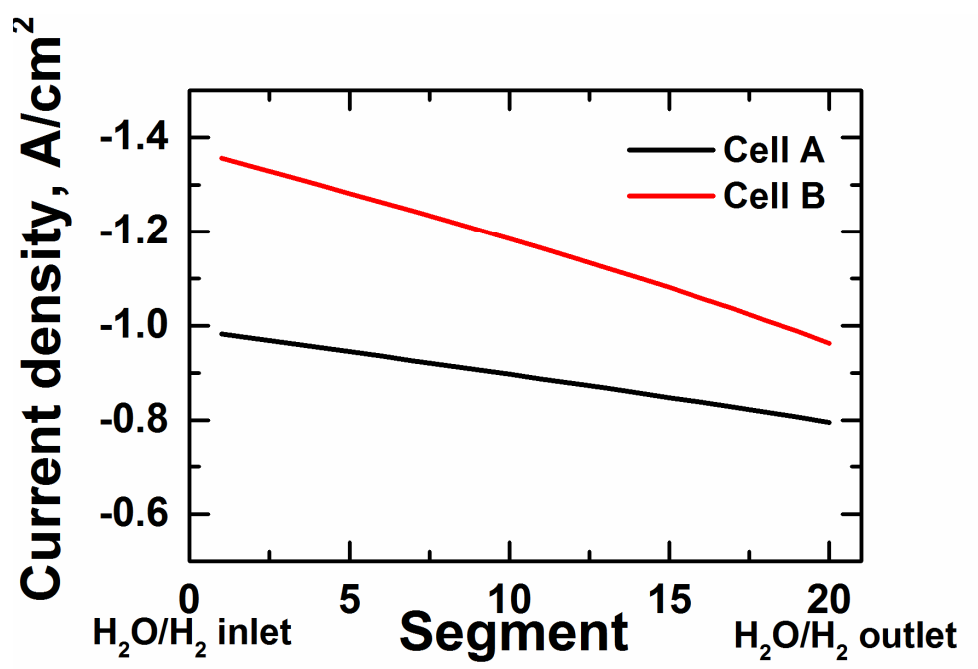

Figure 8. Simulated current distribution along the hydrogen/steam flow direction for Cell $\mathrm{A}$ and $\mathrm{B}$ at the beginning of the potentiostatic durability test period.

The simulated distribution of the overall overpotential onto the different parts of the cells is plotted in Figure 9. The main difference between Cell A and B lies in the two curves: the ohmic part of the overpotential which originates mainly from the voltage drop over the two-layer electrolyte (i.e. the YSZ electrolyte and the CGO barrier layer), and the Ni/YSZ electrode overpotential. For Cell A, the electrolyte takes the largest part of the overpotential ( $184 \mathrm{mV}$ at the inlet), whereas the $\mathrm{Ni} / \mathrm{YSZ}$ electrode overpotential is 84 $\mathrm{mV}$ at the inlet. These two accounts to in total approximately $90 \%$ of the overall cell overpotential. For Cell B, the electrolyte and the Ni/YSZ electrode overpotential at the inlet are 137 and $133 \mathrm{mV}$, respectively, in total amounting to $90 \%$ of the overall cell overpotential. It becomes evident now that the different degradation behavior for Cell A and $\mathrm{B}$ should originate mainly from the difference in $R_{\mathrm{s}}$, which results in different overpotentials over the electrolyte and the $\mathrm{Ni} / \mathrm{YSZ}$ electrode. In comparison to Cell $\mathrm{A}$, Cell B has initially a smaller $R_{\mathrm{S}}$ and $R_{\mathrm{LSC}(\mathrm{F}) / \mathrm{CGO}}$. The difference in the oxygen electrode performance should not be the main cause of the different long-term degradation behavior, as this part of the resistance occupies only a small share in the cell ASR 
$(<10 \%)$. Because Cell B started with a higher current density, the Ni/YSZ electrode overpotential in Cell $\mathrm{B}$ is much larger than that in Cell A, resulting in much larger and irreversible degradation. $84 \mathrm{mV}$ overpotential is probably inside the stable operation window for the Ni/YSZ electrode, whereas $133 \mathrm{mV}$ has caused some irreversible damage as seen in Cell B. For the oxygen electrode, $25 \mathrm{mV}$ overpotential is probably not far from the safe operation window for LSCF/CGO and LSC/CGO.
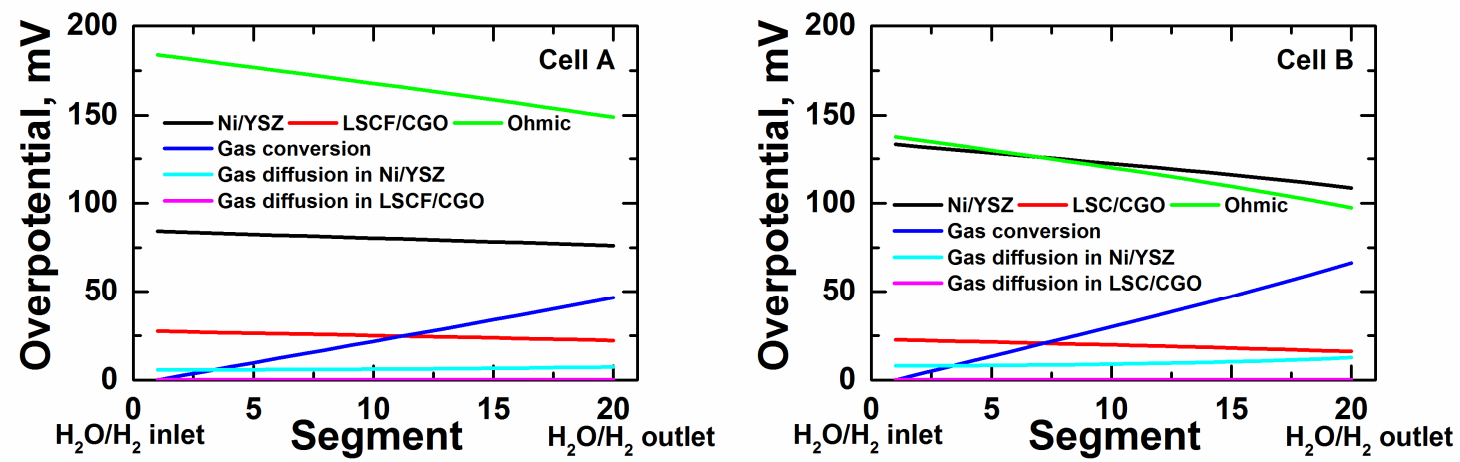

Figure 9. Simulated overpotential distribution along the hydrogen/steam flow direction for Cell $\mathrm{A}$ and $\mathrm{B}$ at the beginning of the potentiostatic durability test period.

As shown in the present work, when operated in potentiostatic mode, fuel electrode supported SOEC cells with better initial performance do not necessarily result in better long-term performance. For these types of cells, $90 \%$ of the total cell polarization is distributed over the electrolyte and the Ni/YSZ electrode. A decrease in the ohmic resistance and the oxygen electrode resistance results in better initial performance, but also increases the Ni/YSZ electrode overpotential and accelerates its degradation. It is hence more important to choose the right operation conditions adapted to different types of cells, ensuring that the electrode overpotential is within its safe operation window. Increasing the electrolyte resistance (e.g. by increasing the electrolyte layer thickness) could be a good strategy for potentiostatic operation, which can reduce the electrode overpotential and its degradation especially in the first few hundred hours. A compromise has to be made in between losing some of the cell initial performance and ensuring acceptable long-term performance. Another strategy could be to improve both the $\mathrm{Ni} / Y S Z$ electrode and the oxygen electrode, to be able to withstand higher electrode overpotentials.

\section{Conclusion}

In this work, we report test results on two types of SOEC cells operated for electrolysis of steam in potentiostatic mode at thermoneutral voltage. Both cells are $\mathrm{Ni} / Y S Z$ fuel electrode supported type, one with LSCF/CGO and the other with LSC/CGO oxygen electrode. In our previous studies, the LSC/CGO cell showed lower degradation rate than the LSCF/CGO cell when tested at $-1 \mathrm{~A} / \mathrm{cm}^{2}$ and $800{ }^{\circ} \mathrm{C}$ in galvanostatic mode. When tested at $750{ }^{\circ} \mathrm{C}$ and $1.29 \mathrm{~V}$ in potentiostatic mode, with a mixture of $50 \% \mathrm{H}_{2} \mathrm{O}+50 \% \mathrm{H}_{2}$ supplied to $\mathrm{Ni} / \mathrm{YSZ}$, the LSC/CGO cell again showed superior initial performance, demonstrating an initial current density of $-1.1 \mathrm{~A} / \mathrm{cm}^{2}$ at $1.29 \mathrm{~V}$. The LSCF/CGO cell showed somewhat inferior performance, with an initial current density of $-0.8 \mathrm{~A} / \mathrm{cm}^{2}$ at $1.29 \mathrm{~V}$. The two cells differ also in the long-term degradation. The LSC/CGO cell showed large and irreversible degradation, while the LSCF/CGO cell degraded in the first $450 \mathrm{~h}$, but afterwards activated and stabilized after 
$1500 \mathrm{~h}$. Both cells reached a current density of about $-0.55 \mathrm{~A} / \mathrm{cm}^{2}$ at the end of the testing period. Detailed impedance analysis indicates that degradation happened mainly at the $\mathrm{Ni} / Y S Z$ electrode for both cells, which is also the dominating factor in the cell ASR along with the ohmic contribution. Based on the experimental results and 2-D electrochemical modeling, the different degradation behavior of the two cells was further correlated to distribution of the overpotential across the cell and along the steam/hydrogen flow direction. Large overpotential on the Ni/YSZ fuel electrode was identified as the main cause of the more pronounced degradation in the cell with the better performing CGO barrier layer and LSC/CGO oxygen electrode. Operation strategies that may help limit degradation were further proposed for fuel-electrode supported cells when operated at thermoneutral voltage.

\section{Acknowledgments}

The authors acknowledge colleagues at DTU Energy, especially Mr. H. Henriksen and Mrs. M. Davodi, for technical assistance and fruitful discussions. Furthermore, the authors would like to acknowledge the financial support from the projects "Development

of SOEC Cells and Stacks" (Energinet.dk project no. 2011-1-10609) and "Towards Solid Oxide Electrolysis Plants in 2020" (Energinet.dk project no. 2015-1-12276).

\section{References}

1. S. D. Ebbesen, S. H. Jensen, A. Hauch, and M. B. Mogensen, Chem. Rev., 114, 10697 (2014).

2. G. Corre and A. Brisse, ECS Trans., 68, 3481 (2015).

3. X. Sun, M. Chen, P. V. Hendriksen, and M. B. Mogensen, in 11th European SOFC \& SOE Forum, p. B1305, Lucerne, Switzerland (2014).

4. J. Schefold, A. Brisse, and H. Poepke, Int. J. Hydrogen Energ., (2017).

5. S. D. Ebbesen, C. Graves, A. Hauch, S. H. Jensen, and M. Mogensen, J. Electrochem. Soc., 157, B1419 (2010).

6. P. Hjalmarsson, X. Sun, Y.-L. Liu, and M. Chen, J. Power Sources, 223, 349 (2013).

7. H. Schichlein, A. C. Muller, M. Voigts, A. Krugel, and E. Ivers-Tiffee, J. Appl. Electrochem., 32, 875 (2002).

8. V. Sonn, A. Leonide, and E. Ivers-Tiffee, J. Electrochem. Soc., 155, B675 (2008).

9. P. Hjalmarsson, X. Sun, Y.-L. Liu, and M. Chen, J. Power Sources, 262, 316 (2014).

10. A. Hauch, K. Brodersen, M. Chen, and M. B. Mogensen, Solid State Ionics, 293, 27 (2016).

11. S. Primdahl and M. Mogensen, J. Electrochem. Soc., 145, 2431 (1998).

12. S. Primdahl and M. Mogensen, J. Electrochem. Soc., 146, 2827 (1999).

13. C. Chatzichristodoulou, M. Chen, P. V. Hendriksen, T. Jacobsen, and M. B. Mogensen, Electrochim. Acta, 189, 265 (2016).

14. R. Knibbe, J. Hjelm, M. Menon, N. Pryds, M. Sogaard, H. J. Wang, and K. Neufeld, J. Am. Ceram. Soc., 93, 2877 (2010).

15. X. D. Zhou, B. Scarfino, and H. U. Anderson, Solid State Ionics, 175, 19 (2004).

16. R. Kiebach, W.-W. Zhang, W. Zhang, M. Chen, K. Norrman, H.-J. Wang, J. R. Bowen, R. Barfod, and P. V. Hendriksen, J. Power Sources, 283, 151 (2015). 